\title{
USE OF VARIABLE VALVE ACTUATION TO CONTROL THE LOAD IN A DIRECT INJECTION, TURBOCHARGED, SPARK- IGNITION ENGINE
}

\author{
Alberto A. Boretti \\ School of Science and Engineering, University of Ballarat, Ballarat, VIC, Australia
}

Copyright (C) 2010 SAE International

\begin{abstract}
Downsizing and Turbo Charging (TC) and Direct Injection (DI) may be combined with Variable Valve Actuation (VVA) to better deal with the challenges of fuel economy enhancement. VVA may control the load without throttle; control the valve directly and quickly; optimize combustion, produce large volumetric efficiency. Benefits lower fuel consumption, lower emissions and better performance and fun to drive. The paper presents an engine model of a 1.6 litre TDI VVA engine specifically designed to run pure ethanol, with computed engine maps for brake specific fuel consumption and efficiency. The paper also presents driving cycle results obtained with a vehicle model for a passenger car powered by this engine and a traditional naturally aspirated gasoline engine. Preliminary results of the VVA system coupled with downsizing, turbo charging and Direct Injection permits significant driving cycle fuel economies.
\end{abstract}

\section{INTRODUCTION}

Turbo Charging (TC), Direct Injection (DI) and Variable Valve Actuation (VVA) are the major areas of development of Spark Ignition (SI) engines, where the well established three way catalytic after treatment force the use of the less efficient stoichiometric operation. Turbo charging permits larger specific power densities and therefore downsizing for better operation over driving cycles. Turbo charging also permits partial recovery of exhaust energy. Direct injection permits better charging efficiencies over the range of speeds and loads, better control of the fuel-to-air ratio, and better resistance to knock due to the in cylinder vaporization of the liquid fuel boosting the conversion efficiency. Variable valve actuation finally permits to control the air quantity and the swirl and tumble charge motions in the cylinder by changing the valve lift and timing of the two intake valves thus improving charging efficiency, combustion evolution and boosting conversion efficiency over the range of engine speeds and loads.

Gasoline engine turbo charging technology was specifically developed for racing applications during the so called Turbo Era in Formula One from 1977 to 1989. The turbo charged port fuel injected Formula One engines of the 80s were able to achieve amazing specific power and torque densities. The F1 turbo engines were 1.5L maximum displacement with layout V- 6 . These engines where developed with the turbine waste gated to control the boost pressure, therefore leaving space for even better results in terms of power density and specific fuel consumption. With reference to these engines, there is the option to more completely recover the exhaust energy to increase the boost pressure, and to further increase the compression ratio due to the charge cooling of direct injection. The 1987 Honda RA167E engine [1], was delivering a maximum brake mean effective pressure (BMEP) of 55.85 bar. Turbo charging is now an area of major interest for new passenger car engines because of the benefits on vehicle economy through recovery of exhaust waste energy and the opportunity to run higher brake mean effective pressures thanks to downsizing during emission cycles [2-11].

Direct injection allows accurate control of the amount of fuel injected and of when the fuel is introduced into the cylinder. Only air passes through the intake valves, no fuel escapes combustion (late injection), the knock resistance is improved by lowering the charge temperature following vaporization of the liquid fuel. Especially if the atomization is fine enough to minimize in-cylinder wall wetting, during transients the engine operates much better than with port fuel injection (PFI). Direct injection has been proposed for stoichiometric and lean burn operation, with typically a side or a central injector location. Despite the central location is the ideal location, the side location permits an easy modification of existing cylinder heads. Direct injection may boost the charging efficiency as well as the fuel conversion efficiency both full and part loads [12-15].

The main issue of the spark ignition engine is the pumping loss due to the traditional throttle-based load control and the deterioration of combustion due to the poor mixture composition and turbulent mixing at part loads. With variable valve actuation, the spark ignition engine may behave similarly to a Diesel engine controlled by quantity of fuel injected. Top and part load efficiencies would 
be lower, but the use of a stoichiometric air-to-fuel mixture will permit better downsizing. Furthermore, the very well established three way catalytic converter technology may permit to meet emissions standards without the negative impacts on the after treatment technology that the lean stratified operation would introduce [16-23].

The electro-hydraulic variable valve actuation technology may be applied to both intake and exhaust valves to fully modify the lift profiles as needed by the engine operation. In addition to valve timing strategies as early intake valve closure or late intake valve opening, valve lift strategies are also possible with variable valve actuation. Valve lift profiles may change not only in maximum lift and opening and closing times, but also in shape. Valve lift profiles may be different for the two intake valves of a typical four valve configuration to further control the swirl and tumble charge motions in the cylinder.

In addition to metering the amount of air introduced within the cylinder and enhance the rate of combustion, variable valve actuation also offers the potential to improve other critical areas of spark ignition engines. These areas include better charging efficiency over the range of engine speeds and loads, improved dynamic response, better combustion evolution, improved operation during catalyst light-off time. Better details of the variable valve actuation system are proposed in a following section.

The most part of gasoline engines now in production are naturally aspirated, port fuel injected, throttle controlled, stoichiometric engines with three ways catalytic after treatment with major advantage the low cost of production. The major downfalls of these engines are not only the low top brake efficiency, generally below $35 \%$, but mainly the large penalties in efficiency reducing the load due to throttling, with efficiencies less than 15\% during operation at 1 bar Brake Mean Effective Pressure (BMEP) and 1,500 rpm.

Figures $1 \mathrm{a}$ and $1 \mathrm{~b}$ present the brake efficiency and the Brake Specific Fuel Consumption (BSFC) of a 4L, naturally aspirated gasoline engine. The compression ratio is 10.5:1. These are computational results obtained with a validated engine efficiency model. Differences vs. experiments done on a properly operating and well maintained engine dynamometer were verified to be less than 5\%. The top efficiency is $35.5 \%$, corresponding to a brake specific fuel consumption of $235 \mathrm{~g} / \mathrm{kWh}$. The brake specific fuel consumption for operation at 1 bar brake mean effective pressure and 1,500 rpm is $575 \mathrm{~g} / \mathrm{kWh}$ corresponding to an efficiency of $14.5 \%$.

Figures $2 \mathrm{a}$ and $2 \mathrm{~b}$ present for comparison the brake efficiency and the BSFC of 1.6L, turbo charged, direct injected, lean burn, Diesel engine. The compression ratio is 16.5:1. Maximum load operation is obtained with an air-to-fuel equivalence ratio of 1.55 . These are computational results obtained with a validated engine model, with differences vs. experiments done on a properly operating and well maintained engine dynamometer verified to be less than $5 \%$.

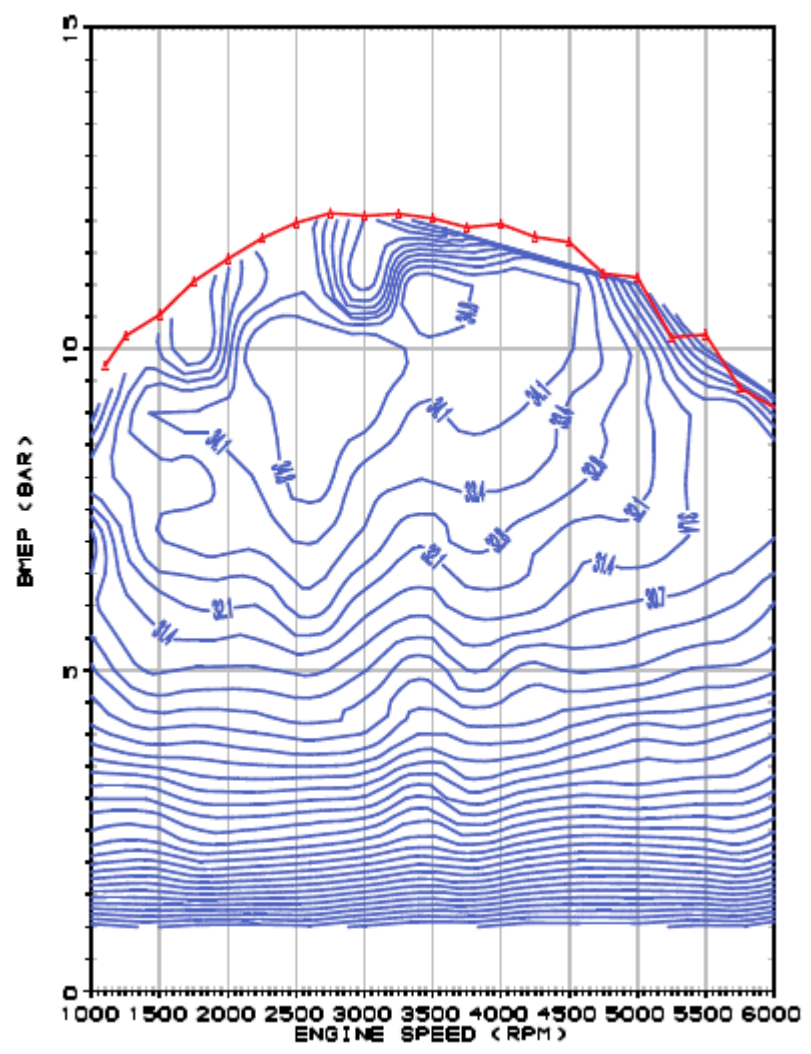

Figure 1.a-Brake efficiency of a naturally aspirated, 4L gasoline engine. 


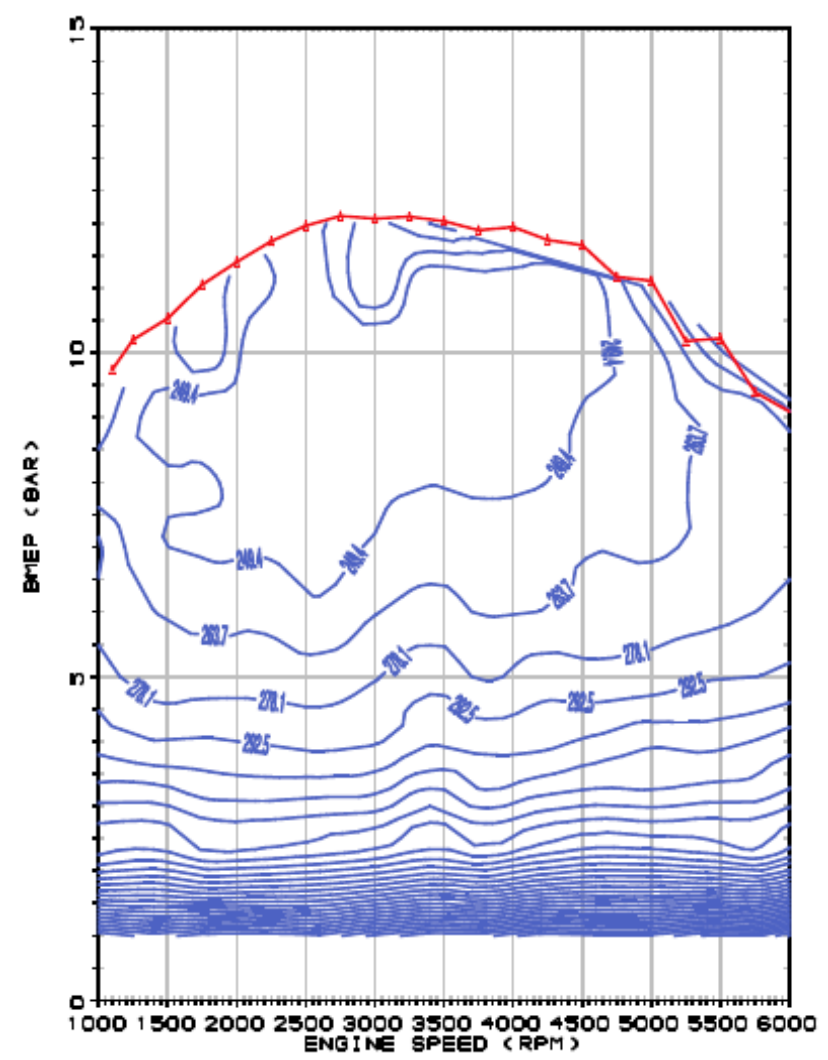

Figure $1 . \mathrm{b}-\mathrm{BSFC}(\mathrm{g} / \mathrm{kWh})$ of a naturally aspirated, $4 \mathrm{~L}$ gasoline engine.

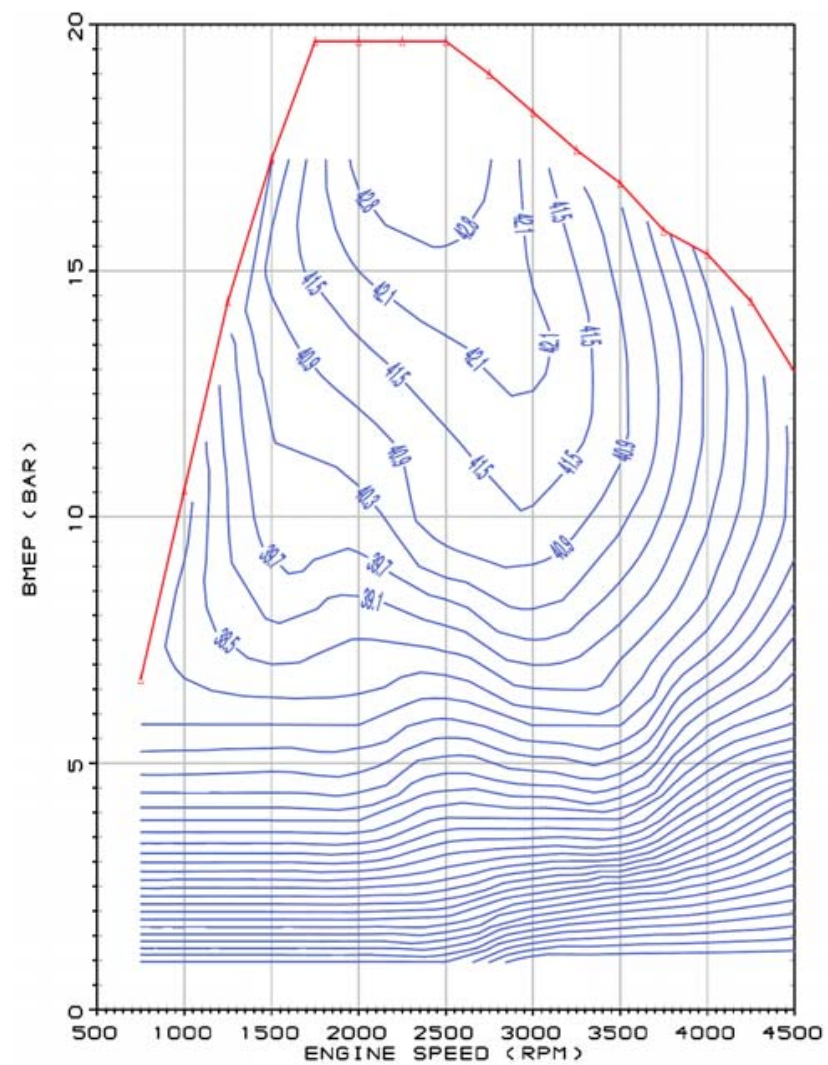

Figure 2.a - Brake efficiency of a turbo charged, directly injected, lean burn 1.6L Diesel engine. 


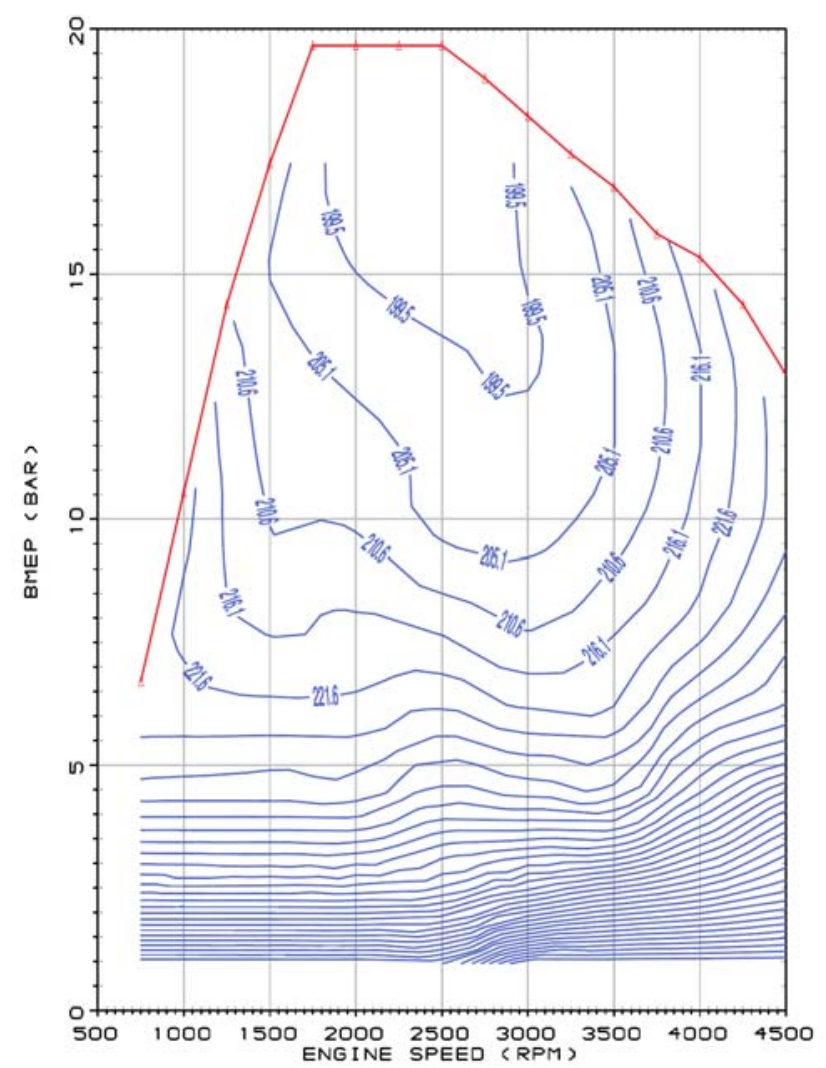

Figure 2.b - BSFC (g/kWh) of a turbo charged, directly injected, lean burn 1.6L Diesel engine.

The top efficiency is $43.5 \%$, corresponding to a brake specific fuel consumption of $194 \mathrm{~g} / \mathrm{kWh}$. The brake specific fuel consumption for operation at 1 bar brake mean effective pressure and 1,500 rpm is $354 \mathrm{~g} / \mathrm{kWh}$ corresponding to an efficiency of $23.8 \%$.

Downsizing further improves the part load benefits. To produce the same instantaneous power, the downsized Diesel engine must run not 1 , but $4 / 1.6=2.5$ bar brake mean effective pressure. The brake specific fuel consumption for operation at 2.5 bar brake mean effective pressure and 1,500 rpm is $280 \mathrm{~g} / \mathrm{kWh}$ corresponding to an efficiency of $30 \%$, i.e. almost three times the efficiency of the naturally aspirated $4 \mathrm{~L}$ gasoline engine. However, the $4 \mathrm{~L}$ gasoline engine will have much better power and torque outputs.

Aim of the paper is to provide two computational assessments. First, a small high power density, turbo charged, direct injection, variable valve actuation engine may provide high power densities, large top brake efficiencies and small penalties in efficiency changing the load. Second, such an engine may operate during driving cycles much more efficiently that large small power density, naturally aspirated, port fuel injected, throttle controlled engines.

First task starts from three validated WAVE [23] engine performance models, a 1.6L and a $2 \mathrm{~L}$ turbo charged, direct injection Diesel engines and a 4L naturally aspirated, port fuel injection, throttle controlled G100 engine, with computed brake efficiencies and specific fuel consumptions vs. engine speed and brake mean effective pressure within a 5\% of measured values. The 2L TDI Diesel above is then used as the baseline for development of the 1.6L E100 and G100 engines.

Diesel and SI engines have quite different port shapes, valve sizes and port flow characteristics. The 1.6L SI engines for G100 and E100 are derived from the 2.0L Diesel engine reducing the stroke to accommodate the higher engine speed. While Diesel diffusion combustion is limited to engine speeds below $4500 \mathrm{Rpm}$, premixed combustion in spark ignition engines works fairly well at almost any speed. Port shapes, valve sizes and port flow characteristics are still not optimal for SI engines. The Diesel engine is further modified replacing the centrally located Diesel direct injector with a centrally located gasoline direct injector and a spark plug, reducing the compression ratio and adopting a variable valve actuation module on the intake valves to control the load throttle less. These changes that could be extremely costly on a real engine require only a few changes in the model. The computed brake efficiencies and specific fuel consumptions vs. engine speed and brake mean effective pressure are expected to be not that far from actual values.

Second task starts from a validated Lotus [24] vehicle simulation model for a full size passenger car equipped with the 4L naturally aspirated, port fuel injection, throttle controlled G100 engine, with computed fuel economies over the new European driving cycle within a $5 \%$ of measured values. The vehicle model is then modified to use the brake specific fuel consumption maps of the $1.6 \mathrm{~L}$ high power density, turbo charged, direct injection, variable valve actuation load controlled engine optimized for E100. These changes that 
could be extremely costly on a real vehicle only require few changes of the model. The computed fuel economies are expected to be not that far from actual values.

Better details of the valve actuation system, as well as of the engine requirements to run ethanol are provided in the following two sections.

\section{THE MULTI-AIR TECHNOLOGY}

Multi-Air is a technology developed by Fiat Research in the last two decades now being used in production passenger cars [16-20] and does not need any proof of concept. The Author had the option at the time to contribute to the R\&D as an employee of Fiat Research. The Fiat Multi air technology is the first fully variable hydraulic valve actuation system on production vehicles.

Figure 3 presents a sketch of the system. Figures $4 \mathrm{a}$ to $4 \mathrm{e}$ present the different strategies for intake valve lift that can be adopted for maximum power with full valve opening, low rpm torque with early valve closing to maximize air trapping, partial load with partial valve opening for load control, engine idle with late valve opening for further load control, urban cycle multi lift for combustion optimization. Basically, the intake valve lift profile may be shaped free of any restriction if not having the adapted profile being within the envelope of the maximum power one. The system has been so far applied to the intake valves of gasoline engines, but may be extended to also actuate exhaust valves and to Diesel engines.

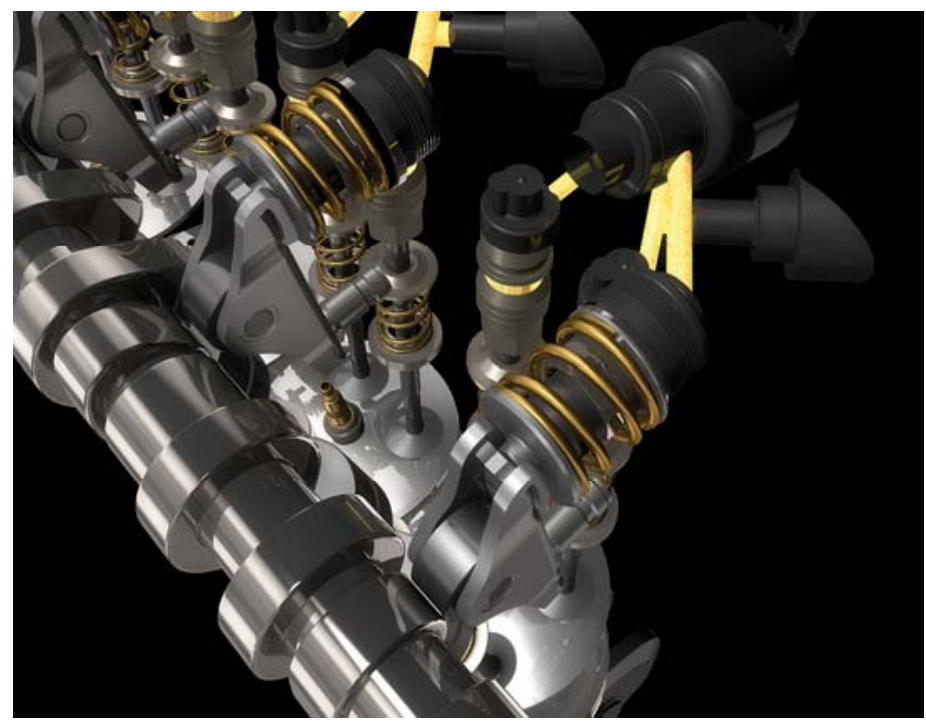

Figure 3 - Multi air cylinder head layout (from [19]).

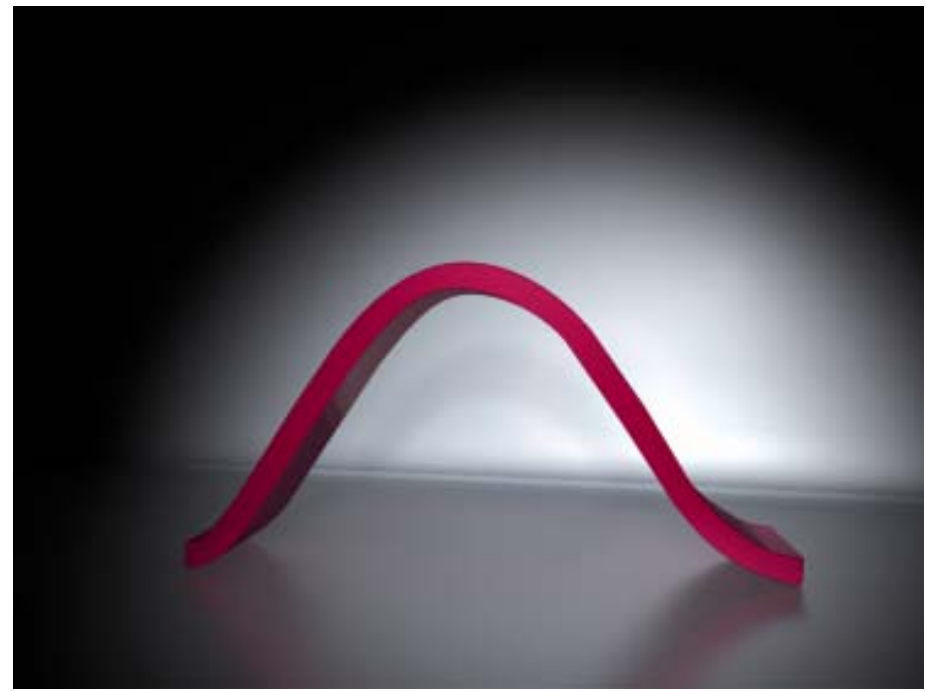

Figure $4 \mathrm{a}$ - Multi air intake valve lift Max power (high speed full load profile from [19]). 


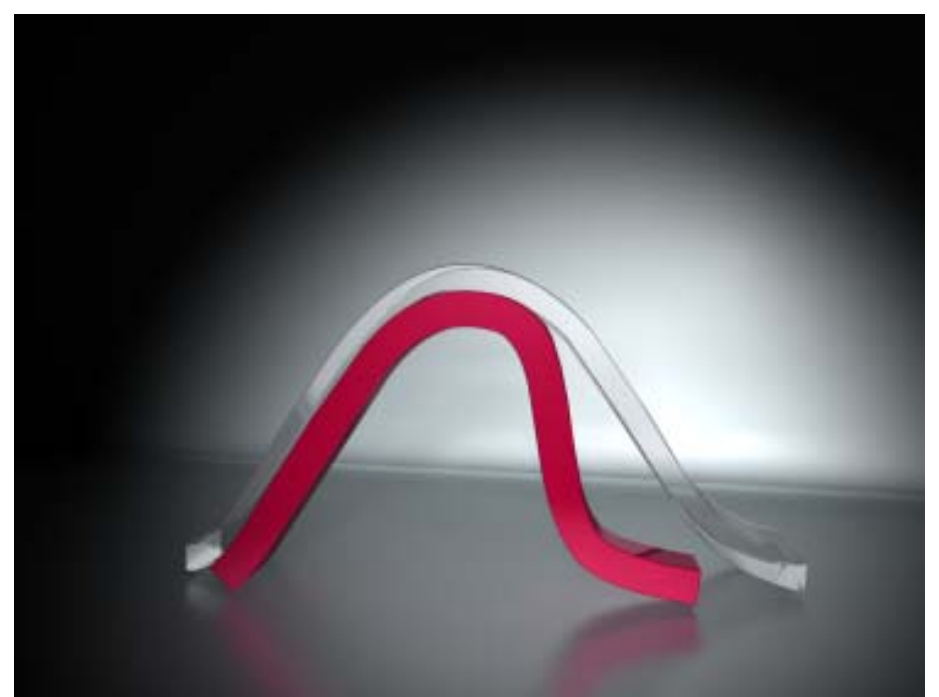

Figure $4 \mathrm{~b}$ - Multi air intake valve lift Low rpm torque (low speed full load from [19]).

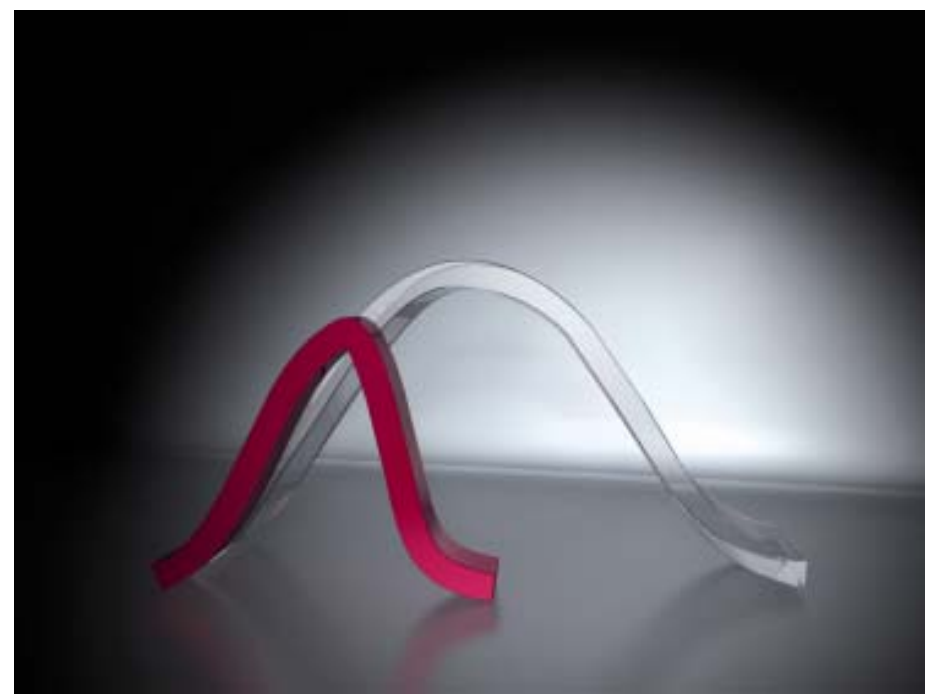

Figure 4c - Multi air intake valve lift Partial load (intermediate loads from [19]).

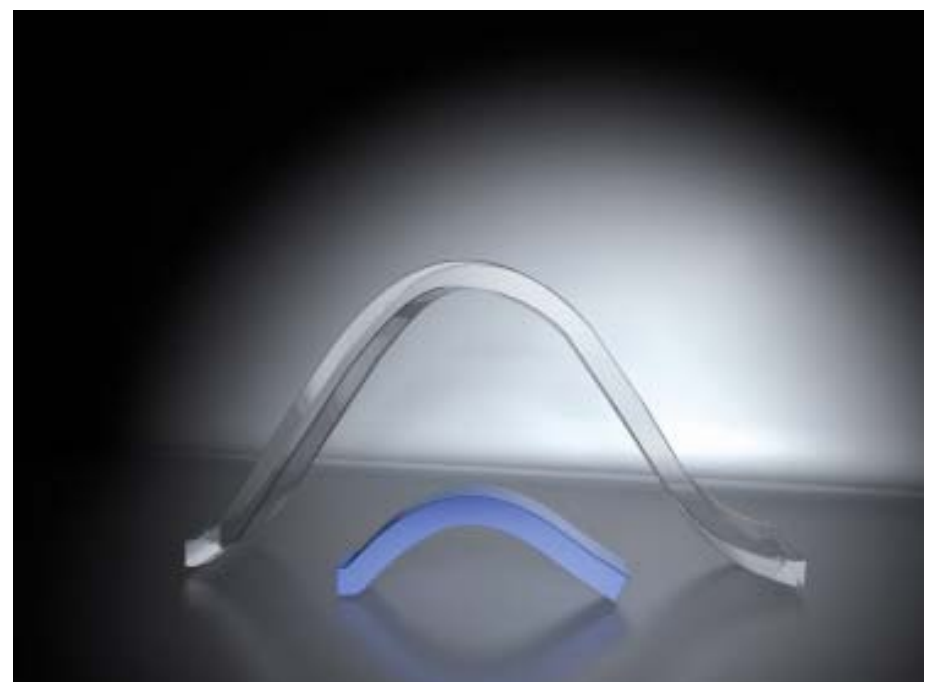

Figure 4d - Multi air intake valve lift for Engine Idle (idle from [19]). 


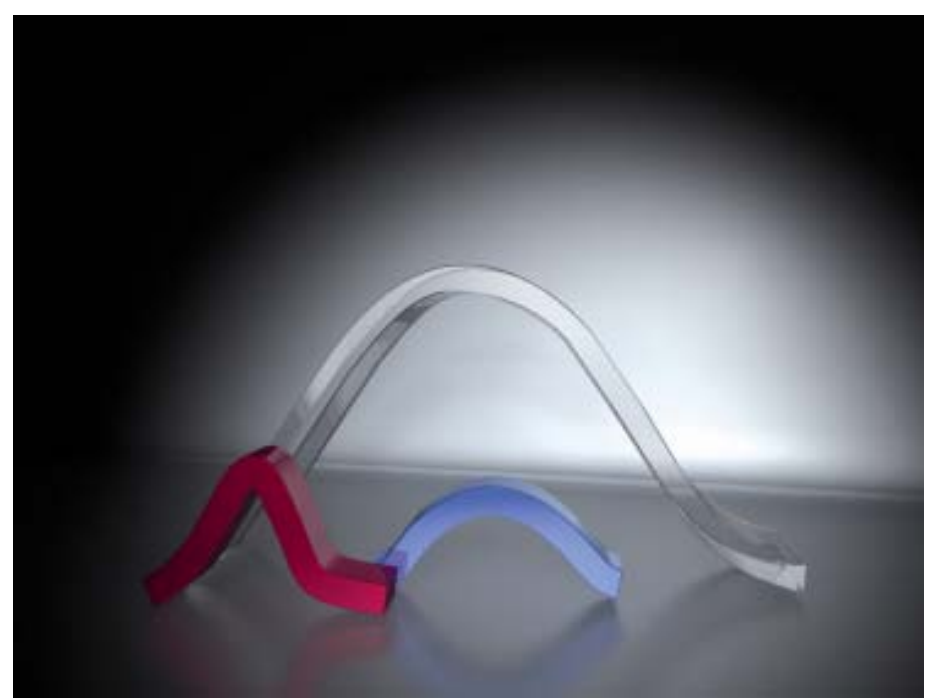

Figure 4e - Multi air intake valve lift Urban cycle (very low loads from [19]).

The operating principle of the system is the following. A piston, driven by a mechanical intake cam lobe, is connected to the intake valve through a hydraulic chamber. This chamber is controlled by an on/off solenoid valve. The solenoid valve is normally open. When the valve is closed, the oil in the hydraulic chamber behaves like a solid body and conveys to the intake valves the lift profile of the cam. When the valve is open, the hydraulic chamber and the intake valves are decoupled, and the intake valve lift does not follow the intake cam profile anymore. Not pushed by the cam, the intake valve then closes under the valve spring action. The final part of the valve closing stroke is controlled by a dedicated hydraulic brake to ensure a soft landing.

Controlling the solenoid valve opening and closing time produces a wide range of optimum intake valve profiles. For maximum power (figure 4a), the solenoid valve is always closed and the valve lift follow the cam profile specifically designed to maximize power at high engine speed. For low rpm Torque (figure 4b), the solenoid valve opens near the end of the valve opening event leading to early intake valve closure. Different strategies are available for part load. For medium loads (figure 4c), the solenoid valve opens much earlier causing the partial opening of the valve. For light loads (figure 4d) the solenoid valve may close once the cam event is already started partially opening the intake valve. The last two actuation modes can be combined in the same intake stroke generating the socalled "Multilift" mode (figure 4e) enhancing turbulence and combustion rate at very low loads. All these strategies are effective in controlling the load reducing the air flow, with the second producing much larger velocities of the incoming air thus producing higher in-cylinder turbulence and rate of combustion.

The Multi air benefits for gasoline engines [19] are up to $10 \%$ increase of maximum power because of the adoption of a poweroriented valve lift profile when power is needed, up to $15 \%$ increase of low rpm torque through early intake valve closure minimizing back flows, up to $10 \%$ reduction of fuel consumption due to the reduction of pumping losses. The Multi air benefits [19] also include the option to optimize the warm-up and reduce emissions introducing internal Exhaust Gas Recirculation by reopening the intake valves during the exhaust stroke and the superior dynamic engine response.

The key development areas of the Multi Air technology applied to spark ignition considered in the paper are integration of Multi Air with Direct Injection and Turbo charging to further improve fuel economy (and transient response) as well as the introduction of more advanced multiple valve opening strategies decoupling operation of the two intake valves of a four valve layout to further reduce emissions producing combined swirl and tumble motions.

\section{HIGH TECH S. I. ENGINE PARAMETERS}

A 2L Diesel engine is modified to run E100 and G100 with a reduced displacement of 1.6L. This requires replacement of the centrally located Diesel direct injector with a centrally located gasoline direct injector and spark plug, reduction of the compression ratio and addition of a variable valve actuation module on the intake valves. These changes that could be extremely costly on a real engine only require a few modification of the model to obtain computed brake efficiencies and specific fuel consumptions vs. engine speed and brake mean effective pressure. The engine is turbo charged with a fixed geometry turbine matching the requirements of the Diesel operation and therefore non optimal. Dimensioning of gas passages is made for the Diesel operation and it is therefore not optimal. The maximum power cam profile is also the one defined for operation of the Diesel and it is therefore not optimal. The engine has charge cooling and cooled exhaust valve recirculation. The turbocharger is waste gated.

Properties of gasoline and ethanol fuels are presented in appendix 1. Properties of methanol and propane are also included in the table as a reference. Ethanol is a fuel receiving large attention for the option to mitigate the effects of climate change cancelling upstream the $\mathrm{CO}_{2}$ production within the engine. Having a much larger knock resistance and heat of vaporization than gasoline, a dedicated 
direct injection ethanol engine may run much higher compression ratios than gasoline and accommodate higher boost pressures and use spark advances closer to maximum brake torque [26]. The engine is running stoichiometric to lower the emission of pollutants below Euro 4 standards with a three way catalytic converter (TWC). Two different pistons are requested to run gasoline and ethanol having very different spray behaviour and requesting very different compression ratios. Piston is modified to run ethanol with a reduced compression ratio of 13:1 or gasoline with a reduced compression ratio of 9:1. Details of piston design to better deal with direct injection of ethanol or gasoline are not considered at this stage. The main engine parameters are presented in Table 1.

Table 1 - Engine parameters.

\begin{tabular}{|c|c|c|}
\hline & E100 & G100 \\
\hline Bore B [mm] & \multicolumn{2}{|c|}{80} \\
\hline Stroke S [mm] & \multicolumn{2}{|c|}{80} \\
\hline Bore to Stroke ratio $\mathrm{B} / \mathrm{S}$ & \multicolumn{2}{|c|}{1} \\
\hline Connecting rod length $[\mathrm{mm}]$ & \multicolumn{2}{|c|}{135} \\
\hline Compression ratio CR & $13: 1$ & $9: 1$ \\
\hline Injection rail pressure [bar] & 300 & 200 \\
\hline Intake valve reference diameter $\mathrm{D}_{\mathrm{i}}[\mathrm{mm}]$ & \multicolumn{2}{|c|}{27} \\
\hline Exhaust valve reference diameter $\mathrm{D}_{\mathrm{e}}[\mathrm{mm}]$ & \multicolumn{2}{|c|}{24} \\
\hline Intake valve maximum lift $\mathrm{h}_{\mathrm{i}}[\mathrm{mm}]$ & \multicolumn{2}{|c|}{8.5} \\
\hline Exhaust valve maximum lift $h_{\mathrm{e}}[\mathrm{mm}]$ & \multicolumn{2}{|c|}{8.5} \\
\hline Intake valve opening IVO $\left[{ }^{\circ}\right.$ crank angle $]$ & \multicolumn{2}{|c|}{$350^{\circ}\left(10^{\circ} \mathrm{BTDC}\right)$} \\
\hline Intake valve closure IVC [ ${ }^{\circ}$ crank angle] & \multicolumn{2}{|c|}{$580^{\circ}\left(40^{\circ} \mathrm{ABDC}\right)$} \\
\hline Exhaust valve opening EVO [ ${ }^{\circ}$ crank angle] & \multicolumn{2}{|c|}{$140^{\circ}\left(40^{\circ} \mathrm{BBDC}\right)$} \\
\hline Exhaust valve closure EVO [ $^{\circ}$ crank angle $]$ & \multicolumn{2}{|c|}{$370^{\circ}\left(10^{\circ}\right.$ ATDC $)$} \\
\hline
\end{tabular}

The fuel injector considered here is a fast, high pressure fuel injector for gasoline direct injection engines ideal for spray stratified lean combustion applications [27]. Operation with gasoline at pressures 50-200 bar permits static flow rates of up to $40 \mathrm{~g} / \mathrm{s}$, minimum linear flow@200 bar 4 mg/pulse, multiple injection capability with hydraulic separation at multiple injection $\leq 0.2$ ms, $\mathrm{D}_{32}$ Sauter mean diameter less than $10 \mu \mathrm{m} @ 200$ bar, DV 90 less than $25 \mu \mathrm{m} @ 200$ bar and cone angles as required by application in between $80^{\circ}$ and $100^{\circ}$.

The injection pressure from the fast actuating, multiple event high pressure injector is increased from 200 to 300 bar with ethanol. With E100, the DI injector maximum flow rate has to increase since E100 only contains $66 \%$ of gasoline energy in volume. The problem is solved using a higher pressure GDI injector specifically developed for much larger engines (the displaced volume for a single cylinder of this engine is only 0.4 litres). Injection is always performed after Intake Valve Closure (IVC). This has the advantage of injecting into hotter gas which helps to insure complete vaporization of the ethanol and prevents or minimizes wall wetting.

The high evaporation enthalpy of ethanol requires detailed examinations regarding the cold start behaviour. Various injection strategies should be adopted to avoid the fuel film on the piston top and ensure that the first injected mass of fuel could also be ignited. The larger amounts of fuel to be injected with ethanol may also increase the oil dilution. Both these aspects are not considered in the paper.

Peak cylinder pressures and turbine inlet temperatures of the following application are compatible with values of Diesel. Peak cylinder pressures are higher than those of today's production gasoline engines. Cost related thermal and structural limitations to boost are not considered in the present paper.

Inlet temperature to turbine below $700 \mathrm{C}$ at full load and high engine speeds require use of EGR, waste gate and fuel enrichment to control. The condition above is much easily provided with ethanol than gasoline.

\section{RESULTS OF ENGINE SIMULATIONS}

Simulations have been performed using the WAVE code [24] with gasoline considered as indolene $\mathrm{C}_{7.3} \mathrm{H}_{13.9}$ and ethanol $\mathrm{C}_{2} \mathrm{H}_{6} \mathrm{O}_{1}$ as liquid fuels. Knock is simply computed with an empirical induction-time correlation model [24 and 28]. Combustion is simulated with a three parameters, predictive SI turbulent combustion model [24 and 29-34]. This model simulates combustion with a flame front propagating from the spark plug location through a simplified geometry. For what concerns the spray behaviour, only the effect of fuel spray evaporation on gas temperature within the cylinder is considered.

The WAVE code presently uses two hardwire sets of data for laminar flame speeds of liquid and gaseous fuels, respectively those of gasoline and methane. This means that the laminar flame speed for ethanol will be underestimated of about $24 \%$. Therefore, the rate of 
variation of burned and entrained mass fractions $\mathrm{M}_{\mathrm{b}}$ and $\mathrm{M}_{\mathrm{e}}$ will be underestimated if the three combustion model parameters $C_{s}, C_{k}$ and $C_{l}$ will not be changed to reproduce the experimental evidence of a faster laminar flame speed with ethanol.

The turbocharger is modelled by introducing non dimensional turbine and corrected compressor maps, made up of speed, mass flow, pressure ratio and efficiency data [24].

Figures $6 \mathrm{a}$ and $6 \mathrm{~b}$ show the computed engine brake efficiency and mean effective pressure for the E100 engine changing the maximum intake valve lift. Controlling the load by variable valve actuation is effective in producing high efficiencies from $25 \%$ of full load. Load control is performed by using the strategies outlined in figures $4 \mathrm{c}$ and $4 \mathrm{~d}$ only. Better results may be achieved also considering options $4 \mathrm{e}$.

Figures $7 \mathrm{a}$ and $7 \mathrm{~b}$ present the brake specific fuel consumption and brake efficiency maps of the Turbo charged, variable valve lift controlled 1.6L E100 engine. Figures $8 \mathrm{a}$ and $8 \mathrm{~b}$ present the brake specific fuel consumption and brake efficiency maps of the Turbo charged, variable valve lift controlled 1.6L G100 engine.

All the curves are throttle-less. The constant IVL\% curves refer to operation with same fraction of maximum intake valve lift all over the speed range. The intake valve opening time also changes. The constant BMEP curves are obtained at different values of maximum valve lift at different speed. In hypothesis the IVL strategy can goes from $0 \%$ to $100 \%$, the load can also be changed throttle-less $0 \%$ to $100 \%$.

These results are computational results with differences vs. experiments done on a properly operating and well maintained engine dynamometer expected to be less than $10 \%$.

For what concerns the E100 engine, the top efficiency is $39.2 \%$, corresponding to a brake specific fuel consumption of $342 \mathrm{~g} / \mathrm{kWh}$. The brake specific fuel consumption for operation at 1 bar brake mean effective pressure and 1,500 rpm is $574 \mathrm{~g} / \mathrm{kWh}$ corresponding to an efficiency of $23.4 \%$. The G100 engine has a top efficiency is $33.2 \%$, corresponding to a brake specific fuel consumption of 251 $\mathrm{g} / \mathrm{kWh}$. The brake specific fuel consumption for operation at 1 bar brake mean effective pressure and 1,500 rpm is $430 \mathrm{~g} / \mathrm{kWh}$ corresponding to an efficiency of $19.4 \%$.

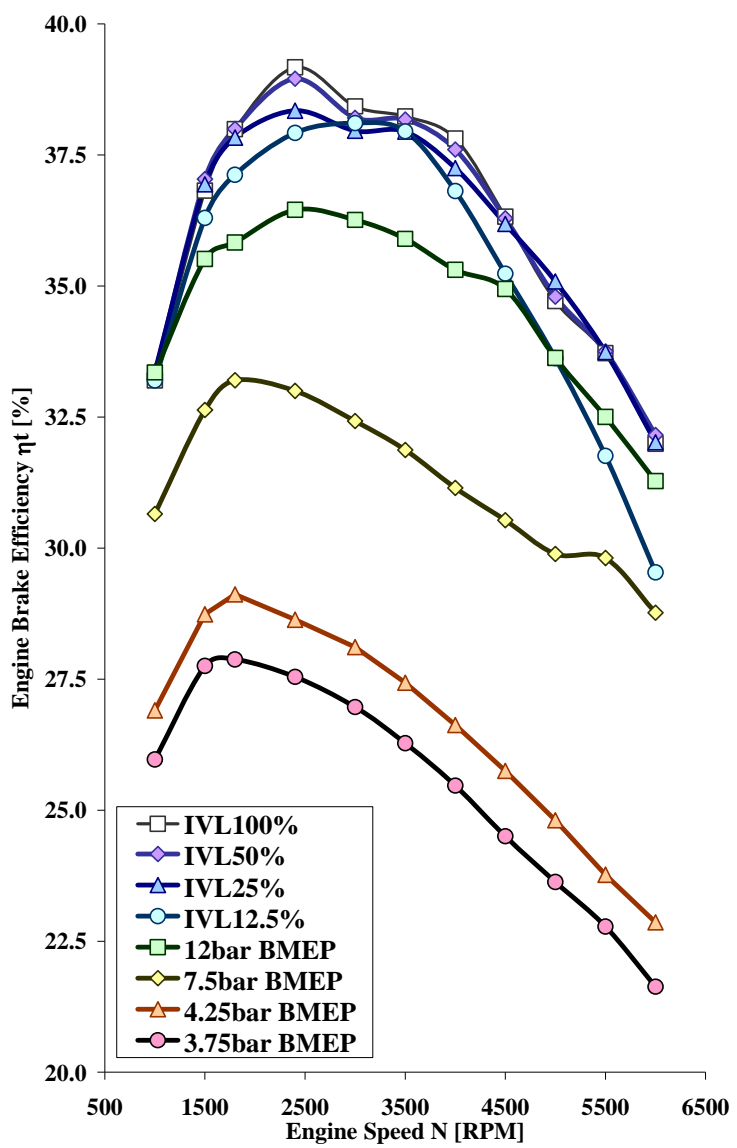

Figure 6.a - Engine brake efficiency for the E100 engine at various intake valve lift (MBT or knock limited spark timing). 


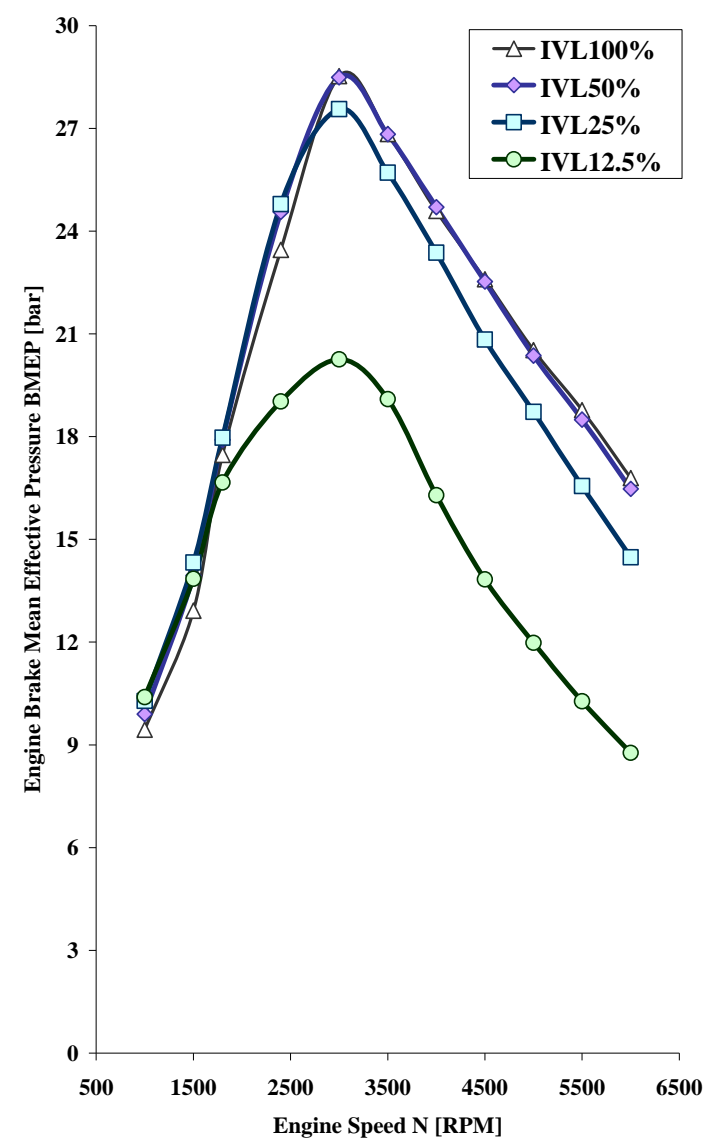

Figure 6.b - Engine BMEP for the E100 engine with various intake valve lift (MBT or knock limited spark timing).

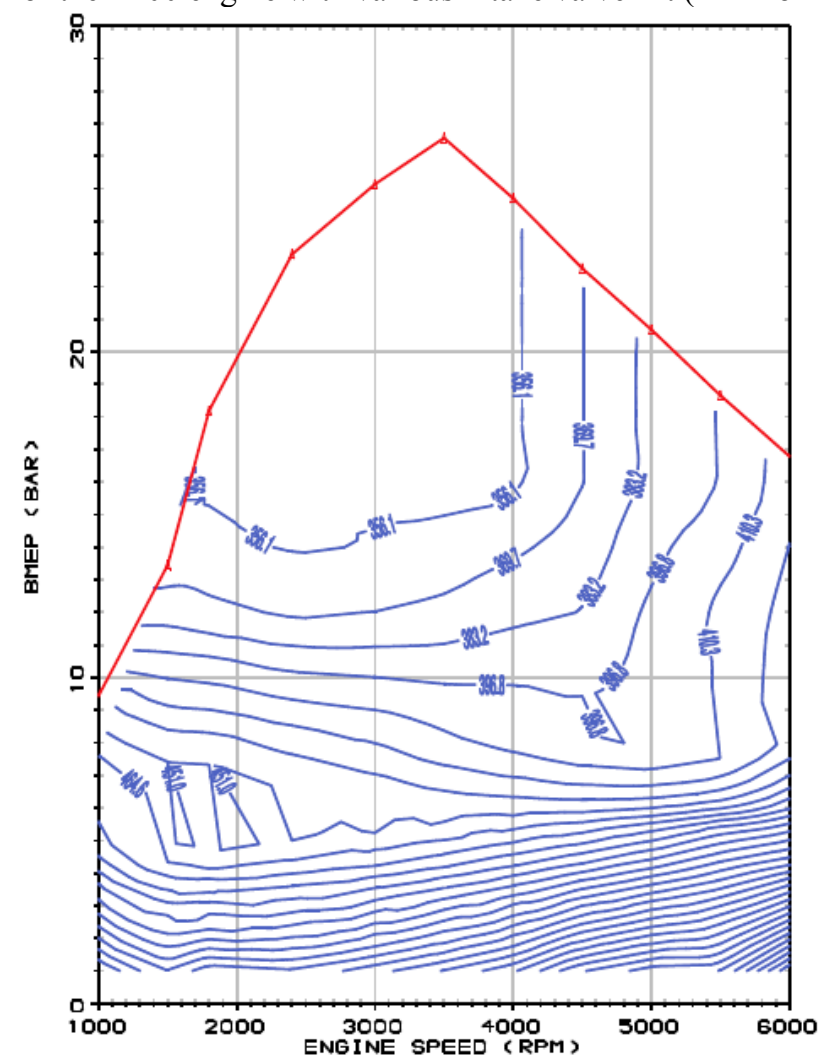

Figure 7.a - BSFC (g/kWh) of the turbo charged, variable valve lift controlled 1.6L E100 engine. 


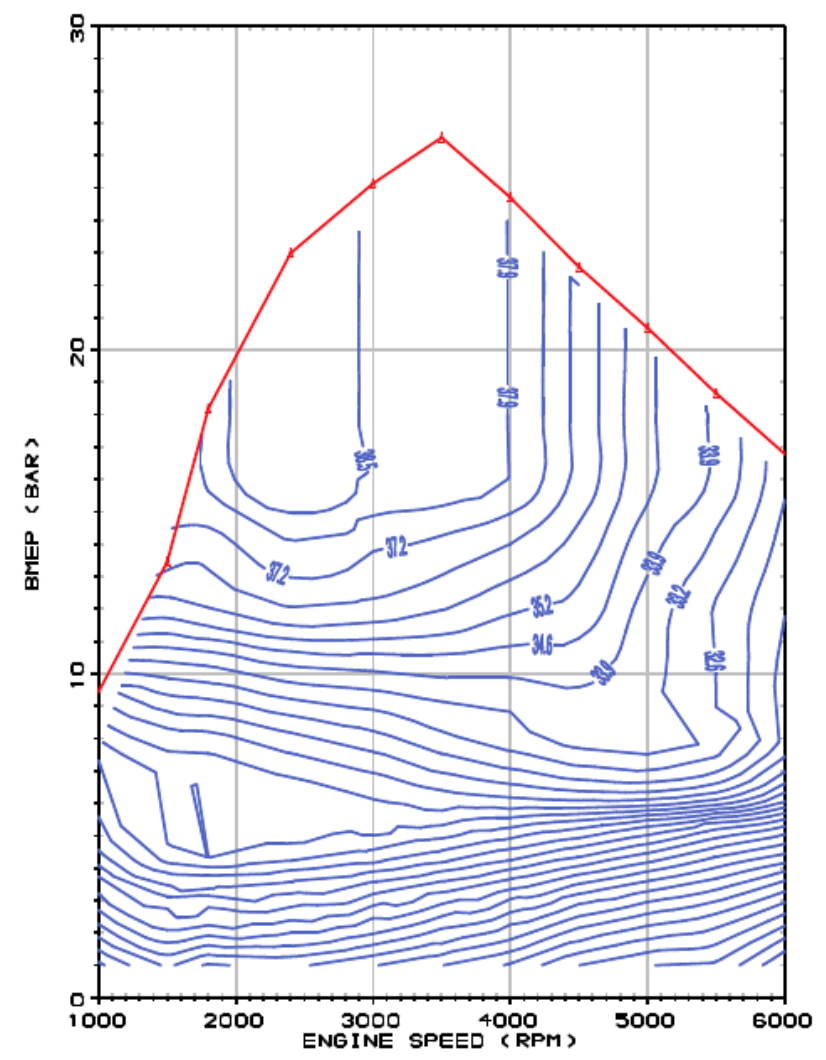

Figure 7.b - Brake efficiency of the turbo charged, variable valve lift controlled 1.6L E100 engine.

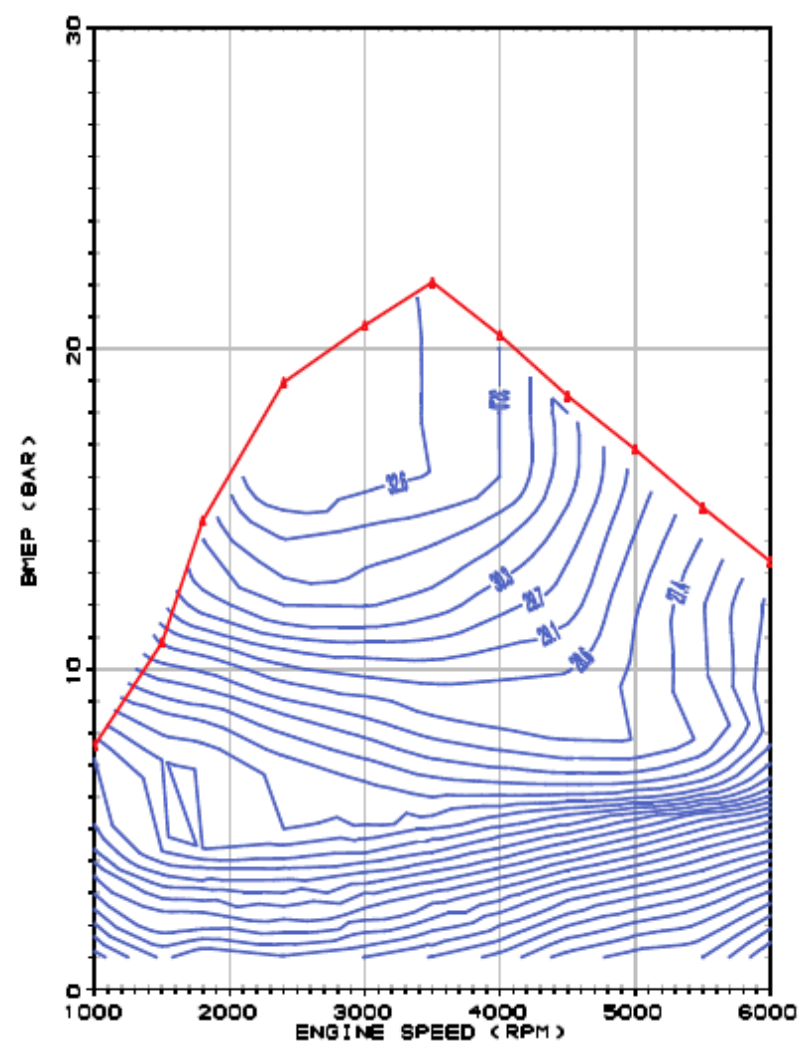

Figure 8.a - BSFC $(\mathrm{g} / \mathrm{kWh})$ of the turbo charged, variable valve lift controlled 1.6L G100 engine. 


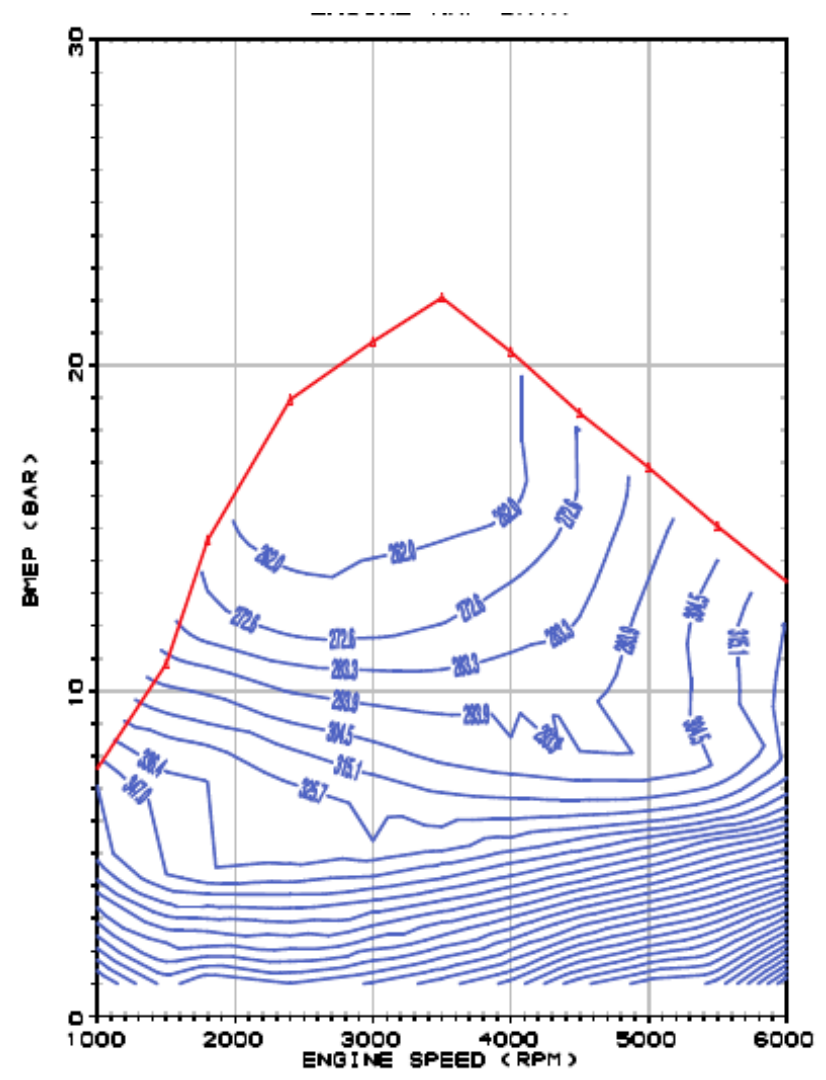

Figure $8 . b$ - Brake efficiency of the turbo charged, variable valve lift controlled 1.6L G100 engine.

Use of these small high power density engines to replace a large low power density engine may considerably improve fuel economy not only for the better top and part load efficiencies, but also for the much better operation following downsizing. To produce the same instantaneous power of a $4 \mathrm{~L}$ gasoline, the downsized 1.6L E100 and G100 engines must run not 1, but 4/1.6=2.5 bar brake mean effective pressure over the driving cycle.

The brake specific fuel consumption for operation at 2.5 bar brake mean effective pressure and 1,500 rpm of the E100 engine is 520 $\mathrm{g} / \mathrm{kWh}$ corresponding to an efficiency of $25.7 \%$, i.e. more than double the efficiency of the naturally aspirated $4 \mathrm{~L}$ gasoline engine. The G100 engine has a brake specific fuel consumption of $370 \mathrm{~g} / \mathrm{kWh}$ corresponding to an efficiency of 22.5. \%.

A dedicated E100 engine using direct injection, turbo charging and variable valve actuation may therefore have full load and part load efficiencies (1) slightly better than a dedicated gasoline engine have same features but a reduced compression ratio, and (2) much better than those of today's naturally aspirated gasoline engines. Despite the lower top and part load efficiencies of a Diesel running leaner with a higher compression ratio, the E100 engine has the advantage vs. Diesel of the much more developed and reliable after treatment system to meet future emission standards for the stoichiometric operation and the higher power density permitted by running higher engine speeds.

\section{RESULTS OF VEHICLE SIMULATIONS}

New European Driving Cycle (NEDC) simulations have then been performed for a large Full size passenger car with the Lotus Vehicle Simulation software [25]. The model has been validated for the car equipped with the 4L naturally aspirated, port fuel injection, throttle controlled G100 engine, with computed fuel economies within a 5\% of measured values. The vehicle model is then modified to use the brake specific fuel consumption maps of the 1.6L high power density, turbo charged, direct injection, variable valve actuation load controlled engines optimized for E100 and G100. These changes that could be extremely costly on a real vehicle just require a few modification of the model to obtain fuel economies that are expected to be not that far from actual values.

Fuel economy is measured over test cycles. The ECE+EUDC cycle is a test cycle performed on a chassis dynamometer used for emission certification of light duty vehicles in Europe [EEC Directive 90/C81/01]. The entire cycle includes four ECE segments, repeated without interruption, followed by one EUDC segment. Before the test, the vehicle is allowed to soak for at least 6 hours at a test temperature of $20-30^{\circ} \mathrm{C}$. It is then started and the emission sampling begins at the same time. This cold-start procedure is also referred to as the New European Driving Cycle (NEDC). The ECE cycle is an urban driving cycle, also known as UDC. It was devised to represent city driving conditions, e.g. in Paris or Rome. It is characterized by low vehicle speed, low engine load, and low exhaust gas temperature. The EUDC (Extra Urban Driving Cycle) segment has been added after the fourth ECE cycle to account for more 
aggressive, high speed driving modes. The maximum speed of the EUDC cycle is $120 \mathrm{~km} / \mathrm{h}$. Table 2 summarizes the parameters for both the ECE and EUDC cycles. The main vehicle parameters are summarized in Table 3.

Table 2 - Main characteristics of ECE and EUDC cycles.

\begin{tabular}{||c|c|c||}
\hline Characteristics & ECE 15 & EUDC \\
\hline Distance $[\mathrm{km}]$ & $4 \times 1.013=4.052$ & 6.955 \\
\hline Duration $[\mathrm{s}]$ & $4 \times 195=780$ & 400 \\
\hline Average Speed $[\mathrm{km} / \mathrm{h}]$ & 18.7 (with idling) & 62.6 \\
\hline Maximum Speed $[\mathrm{km} / \mathrm{h}]$ & 50 & 120 \\
\hline
\end{tabular}

Table 3 - Vehicle parameters.

\begin{tabular}{||c|c|}
\hline Mass $\mathrm{m}[\mathrm{kg}]$ & 1810 \\
\hline Frontal area $\mathrm{A}\left[\mathrm{m}^{2}\right]$ & 2.250 \\
\hline Drag coefficient $\mathrm{C}_{\mathrm{D}}$ & 0.298 \\
\hline Rolling tire radius $\mathrm{R}[\mathrm{m}]$ & 0.3160 \\
\hline Transmission & 5 -speed automatic \\
\hline Transmission ratios & $3.22 / 2.29 / 1.55 / 1.00 / 0.75$ \\
\hline Final drive ratio & 2.730 \\
\hline
\end{tabular}

The 4L, in-line six cylinders, throttle body controlled, naturally aspirated gasoline engine with max. power $190 \mathrm{~kW}$ and maximum torque $380 \mathrm{~N} \cdot \mathrm{m}$ is replaced first by the high tech, 1.6L, in-line four, valve lift controlled, turbo charged G100 engine described above, having $115 \mathrm{~kW}$ maximum power and $305 \mathrm{~N} \cdot \mathrm{m}$ maximum torque, then by the high tech, 1.6L, in-line four, valve lift controlled, turbo charged E100 engine described above, having $140 \mathrm{~kW}$ maximum power and $365 \mathrm{~N} \cdot \mathrm{m}$ maximum torque.

Downsizing does not permit same top speed and acceleration of the large gasoline. However, a climate change and road safety conscious society can not afford to use very inefficient engines in large passenger cars for just having power and torque outputs well in excess of what is allowed to use by speed limits $(110 \mathrm{~km} / \mathrm{h}$ on highway and $50 \mathrm{~km} / \mathrm{h}$ within populated areas in Victoria).

The proposed $1.6 \mathrm{~L}$ is the correct displacement for a high power density, turbocharged, directly injected engine with ethanol when motoring full size passenger cars, still providing large power margins for fun driving and climbing of hills or towing. Maximum speed is indeed $215 \mathrm{~km} / \mathrm{h}$ with the $1.6 \mathrm{~L}$ ethanol engine, vs. the $230 \mathrm{~km} / \mathrm{h}$ of the $4 \mathrm{~L}$ gasoline, with gradability, grade velocity and towing being also modestly affected.

Vehicle, tyre, driveline and gearbox data are kept constant, as well as the shift strategy, that is the one defined for optimum use of the $4 \mathrm{~L}$ engine. During braking the fuel flow rate is the zero BMEP value for the selected speed.

Figures 9 and 10 present the operating BMEP points vs. engine speed for the $4 \mathrm{~L}$ and the $1.6 \mathrm{~L}$ engines. The displacement effect shifts up by a factor of 4/1.6 the operating BMEP of the small engines. The naturally aspirated gasoline engine works the most of the time at 1.5 bar BMEP and $1500 \mathrm{rpm}$, while the turbocharged E100 and G100 engines work the most of the time at 3.75 bar BMEP and 1500 rpm. Table 4 summarizes the fuel economy results of the different engines.

Table 4 - Fuel consumption results for the Full size passenger car equipped with the 4L and 1.6L engines.

\begin{tabular}{||c|c|c|c|}
\hline \hline Engine & 4L NA G100 & 1.6 TDI G100 & 1.6 TDI E100 \\
\hline Fuel specific weight & 0.750 & 0.750 & 0.786 \\
\hline Fuel lower calorific value $[\mathrm{KJ} / \mathrm{Kg}]$ & 43,200 & 43,200 & 26,800 \\
\hline Litres per $100 \mathrm{~km}$ & 11.3 & 8.4 & 10.3 \\
\hline Km per Litre & 8.8 & 11.9 & 9.7 \\
\hline Grams per Test & 936 & 684 & 89 \\
\hline Grams per KM & 85 & 2086 & 2732 \\
\hline Mean Consumption $[\mathrm{g} / \mathrm{h}]$ & 2858 & 386 & 492 \\
\hline Mean Spec. Consumption $[\mathrm{g} / \mathrm{kwh}]$ & 512 & 21.6 & 27.3 \\
\hline Overall Cycle Efficiency $\%$ & 16.3 & \\
\hline
\end{tabular}

The $4 \mathrm{~L}$ gasoline engine uses $936 \mathrm{~g}$ of a fuel having $\mathrm{LHV}=43.2 \mathrm{MJ} / \mathrm{Kg}$ and density $750 \mathrm{~kg} / \mathrm{m}^{3}$ to cover over the $1180 \mathrm{~s}$ total cycle time the $11.028 \mathrm{~km}$ distance travelled of the NEDC, for a fuel consumption of 11.3 litres per $100 \mathrm{~km}$.

Even if the transmission is not optimized for the new engine, and no weight reduction is considered replacing the large naturally aspirated gasoline engine with the smaller turbo charged engines, the $1.6 \mathrm{~L}$ E100 engine only uses $896 \mathrm{~g}$ of a fuel having LHV=26.8 $\mathrm{MJ} / \mathrm{Kg}$ and density $786 \mathrm{~kg} / \mathrm{m}^{3}$, for a fuel consumption of 10.365 litres per $100 \mathrm{~km}$. 


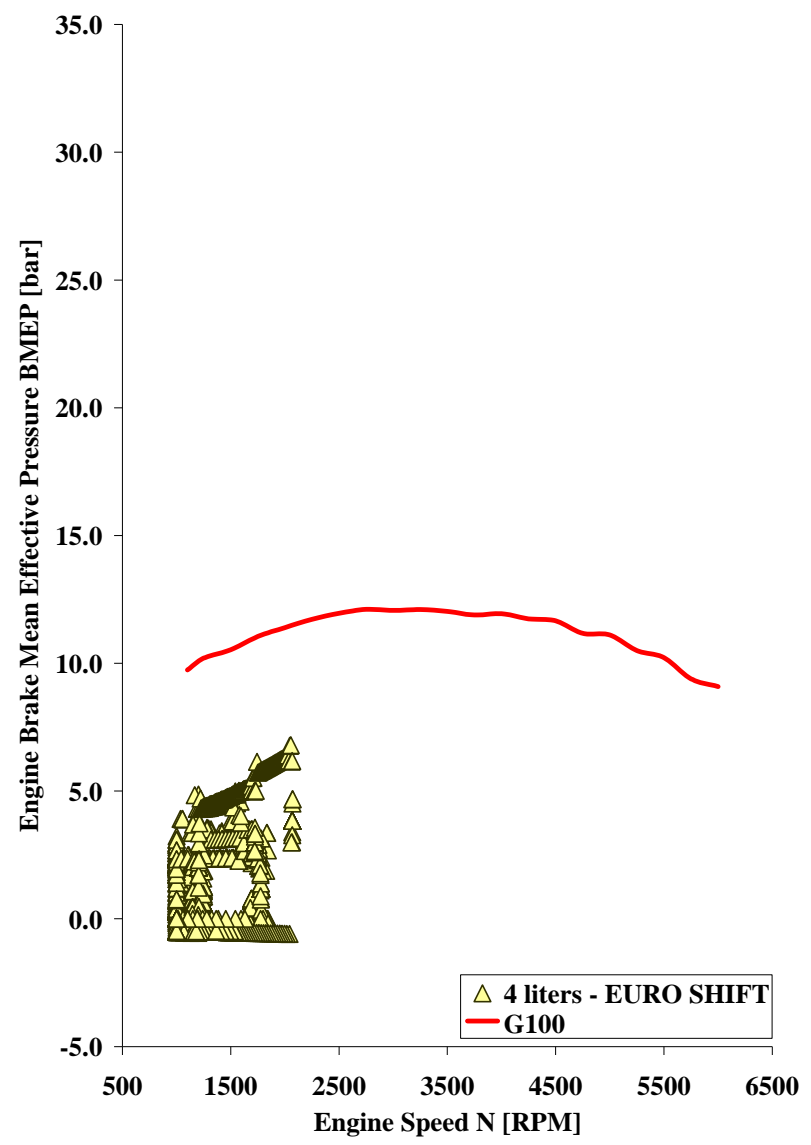

Figure 9 - Engine BMEP during the NEDC for the naturally aspirated 4L engine.

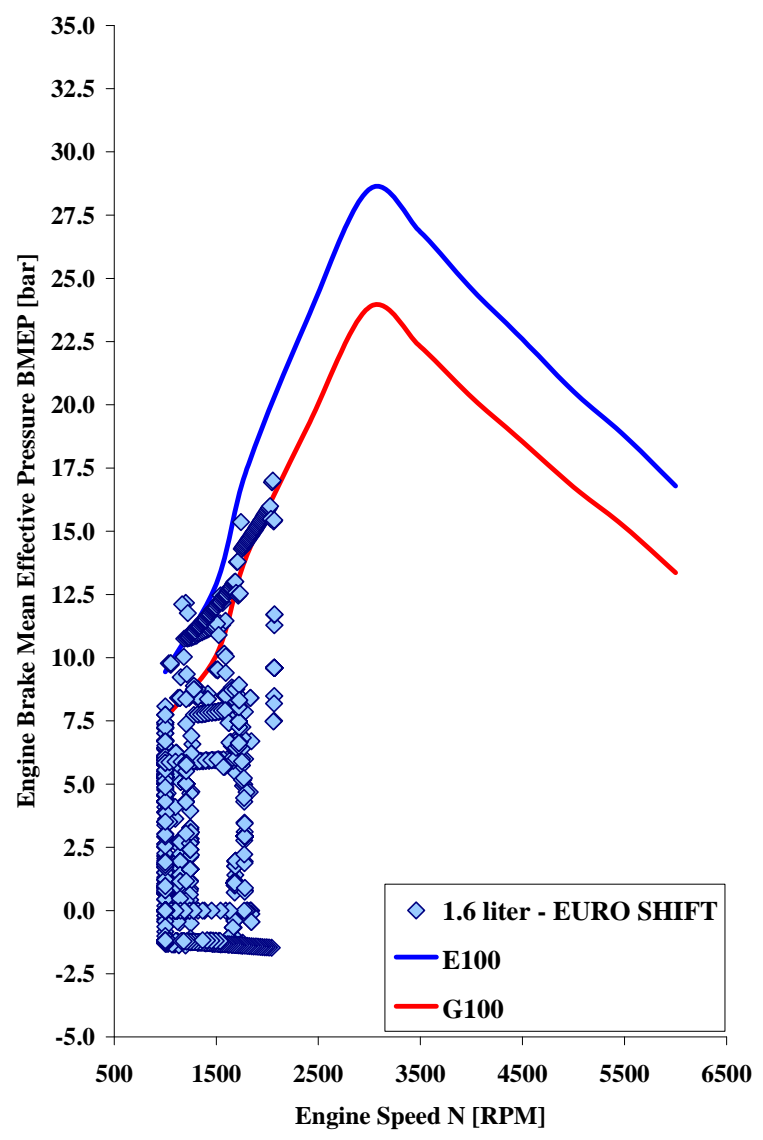

Figure 10 - Engine BMEP during the NEDC for the turbocharged 1.6L engines. 
In terms of fuel energy, the small high tech E100 engine therefore uses $40 \%$ less fuel energy than one large naturally aspirated low tech gasoline engine, permitting an even better driving range with one full fuel tank despite of the much lower energy content of E100.

This is due to the higher BMEP permitted by downsizing (2.5 times larger operating BMEP following the displacement ratio), the larger top brake efficiency permitted by high compression ratio, the cooling due to direct injection cooling, the high boost from turbo charging partially recovering the exhaust waste heat, the spark advances closer to maximum brake torque, and the larger part load efficiencies due to the factors above plus the load control throttle-less by changing the lift of the intake valves.

\section{CONCLUSIONS}

The paper has provided two computational assessments. First, a small high power density, turbo charged, direct injection, variable valve actuation load controlled engine optimized for E100 (pure ethanol) may run higher compression ratios and boost pressures and use better spark advances than same engine optimized for G100 (pure gasoline) thanks to the larger octane number and heat of vaporization of E100, providing better fuel conversion efficiencies.

Second, small high power density, turbo charged, direct injection, variable valve actuation load controlled engines optimized for E100 or G100 may operate during driving cycles much more efficiently that large small power density, naturally aspirated, port fuel injection, throttle controlled E100 or G100 engine thanks to the much better part load efficiency for same instantaneous brake torque and speed of the engine, providing much better fuel energy usage.

The paper provides a first description of how a state-of-the-art pure ethanol engine designed using fast actuating high pressure fuel direct injection, high boost turbo charging and fully variable valve actuation. Extensively validated engine and vehicle simulations packages have been used to produce engine brake specific fuel consumption maps and vehicle fuel economy over driving cycles expected to be within $5 \%$ accuracy vs. experiments.

Direct fuel injection and turbo charging are the two key features pure ethanol engines should have to take full advantage of ethanol's higher research octane number and heat of vaporization. Direct injection permits to cool down the charge and improve the knock tendency. Turbo charging recover part of the exhaust energy. Direct injection and turbo charging permits higher compression ratio, higher boost pressure and spark advances less limited by knock and more close to maximum brake torque values for improved fuel conversion efficiency and increased power density.

The increased fuel conversion efficiency and the increased power density considerably improve vehicle fuel economy over driving cycles. The increased fuel conversion efficiency reduces the amount of fuel requested for a certain BMEP, the increased power density permits through downsizing operation at higher BMEP having better efficiencies.

The proposed direct injection, turbo charged pure ethanol engine basically differs from a gasoline engine in the direct injector selection, the direct injector operating pressure, the piston shape and the compression ratio. With reference to gasoline, the E100 engine has an increased injection pressure (300 bar vs. 200 bar) and an increased compression ratio (13:1 vs. 9:1). The ethanol engine also has a different piston shape to better deal with the ethanol spray.

Improvements in power and torque vary from 20 to $28 \%$ over the range of engine speed, while the fuel conversion efficiency increases 17 to $23 \%$, or 5.70 to 6.25 points, up to values about $40 \%$ in the ethanol engine vs. the parent gasoline engine. Despite of the higher compression ratio, the closer to maximum brake torque spark advances and the reduced opening of the waste gate controlling the turbine, the E100 engine still have similar resistance to knock than the gasoline engine.

Variable valve actuation has been considered only for throttle-less load control to reduce the efficiency penalties reducing the load. Brake efficiencies larger than those of today's naturally aspirated gasoline engines are obtained from $25 \%$ of full load over the full range of engine speed. The variable valve actuation technology offers the potential of better charging efficiency over the range of engine speeds and loads, improved dynamic response, better combustion evolution, improved operation during catalyst light-off time.

When compared to a low tech $4 \mathrm{~L}$, throttle controlled, naturally aspirated gasoline engine to power a large Full size passenger car sedan, the small high tech turbo charged E100 engine with variable valve actuation use $43 \%$ less fuel energy over the NEDC.

The proposed results could help a move back by Original Equipment Manufacturer to vehicle powered by pure ethanol engines in markets like Brazil where ethanol is widely available with the embedded large advantages for economy, energy security and environment.

\section{REFERENCES}

1. Goto, O. et al., "Honda Formula One Turbo-charged V6 1.5L Engine", SAE P. 890877. 
2. Roth J.A., Guzzella L., "Modelling engine and exhaust temperatures of a mono-fuelled turbocharged compressed-natural-gas engine during warm-up", PROCEEDINGS OF THE INSTITUTION OF MECHANICAL ENGINEERS PART D-JOURNAL OF AUTOMOBILE ENGINEERING, vol. 224, pp.99-115, 2010.

3. Khiar D., Lauber J., Guerra T.M., et al., "Turbocharged spark ignition engine modelling and control strategy", INTERNATIONAL JOURNAL OF VEHICLE DESIGN, vol.48, no.3-4, pp.255-270, 2008.

4. Ma F.H., Ding S.F., Wang Y., et al., "Study on combustion behaviors and cycle-by-cycle variations in a turbocharged lean burn natural gas SI engine with hydrogen enrichment", INTERNATIONAL JOURNAL OF HYDROGEN ENERGY, vol.33, no.23, pp.7245-7255, 2008

5. Leroy T., Chauvin J., Le Solliec G., et al., "Air path estimation for a turbocharged SI engine with variable valve timing", PROCEEDINGS OF THE AMERICAN CONTROL CONFERENCE, pp.3034-3039, 2007.

6. Lecointe, B. and Monnier, G., "Downsizing a Gasoline Engine Using Turbocharging with Direct Injection", SAE P. 2003-010542 .

7. Shahed S.M., Bernardini, L.L., and Middlemass, C., "Advanced Gasoline Engine Turbo charging Technology for Fuel Economy Improvements“, SAE P.2004-01-0988.

8. Bauer, K.-H., and Shahed, S. M., Parametric Studies of the Impact of Turbocharging on Gasoline Engine Downsizing“, SAE P.2009-01-1472.

9. Lake, T. H., "Turbocharging Concepts for Downsized DI Gasoline Engines", SAE P.2004-01-0036.

10. Ito N., et al., "Development of a 4-Cylinder Gasoline Engine with a Variable Flow Turbo-charger", SAE P.2007-01-0263.

11. Kirwan, J.E., et al., "3-Cylinder Turbocharged Gasoline Direct Injection: A High Value Solution for Low CO2 and NOx Emissions", SAE P.2010-01-0590.

12. Morita, K., et al., "Emission Reduction of a Stoichiometric Gasoline Direct Injection Engine“, SAE P.2005-01-3687.

13. Stone, R., et al., "Combustion Imaging and Analysis in a Gasoline Direct Injection Engine“, SAE P.2004-01-0045.

14. Spicher, U., et al., "A Basic Experimental Study of Gasoline Direct Injection at Significantly High Injection Pressures", SAE P.2005-01-0098.

15. Christie, M., "DI Boost: Application of a High Performance Gasoline Direct Injection Concept", SAE P.2007-01-1410.

16. http://www.ae-plus.com/Technology\%20News/tn-INA-Uniair-june\%202006.htm (retrieved January 18, 2010).

17. http://www.fiat.co.uk/Content/?id=10857 (retrieved 5-5-2010)

18. http://www.fiat.co.uk/Content/Article.aspx?id=16873 (retrieved 5-5-2010)

19. http://www.fptmultiair.com/flash_multiair_eng/home.htm

20. Bernard, L., and Rinolfi, R., "The future of engine technology", SAE P. 2001-24-0086.

21. Baratta M., Spessa E., Mairone P., "Numerical investigation of turbolag reduction in HD CNG engines by means of exhaust valve variable actuation and spark timing control", INTERNATIONAL JOURNAL OF AUTOMOTIVE TECHNOLOGY Vol.11,no.3 Pp.289-306,JUN 2010.

22. Ma J., Zhu G.G., Schock H., "A Dynamic Model of an Electropneumatic Valve Actuator for Internal Combustion Engines", JOURNAL OF DYNAMIC SYSTEMS MEASUREMENT AND CONTROL-TRANSACTIONS OF THE ASME Vol.132,no.2, 2010 .

23. Gillella P., Sun Z.X., "Modeling and Control Design of a Camless Valve Actuation System", 2009 AMERICAN CONTROL CONFERENCE, VOLS 1-9 Book Series: PROCEEDINGS OF THE AMERICAN CONTROL CONFERENCE, Pp.2696$2701,2009$.

24. http://www.ricardo.com/en-gb/Software/Productoffering--description/WAVE1/ (retrieved January 8, 2010).

25. http://www.lesoft.co.uk/index1.html (retrieved January 20, 2010).

26. Alberto A. Boretti, "Analysis of design of pure ethanol engines", SAE P. 10SFL-0004.

27. http://delphi.com/shared/pdf/ppd/pwrtrn/gas_multec_gdifsc.pdf

28. Douaud, A. M. and P. Eyzat. "Four-Octane-Number Method for Predicting the Anti-Knock Behavior of Fuels and Engines", SAE P. 780080 .

29. Blizard, Norman C., and James C. Keck. "Experimental and Theoretical Investigation of Turbulent Burning Model for Internal Combustion Engines", SAE P. 740191.

30. Hires, S. D., R. J. Tabaczynski, and J. M. Novak. "The Prediction of Ignition Delay and Combustion Intervals for a Homogeneous Charge, Spark Ignition Engine", SAE P.780232.

31. Tabaczynski, Rodney J., Frederick H. Trinker, and Ben A. S. Shannon. "Further Refinement and Validation of a Turbulent Flame Propagation Model for Spark-Ignition Engines". Combustion and Flame Vol. 39 (1980), pp. 111-121.

32. Morel, T., C. I. Rackmil, R. Keribar, and M. J. Jennings. "Model for Heat Transfer and Combustion in Spark Ignited Engines and Its Comparison with Experiments", SAE P. 880198.

33. Wahiduzzaman, Syed, Thomas Morel, and Stephen Sheard. "Comparison of Measured and Predicted Combustion Characteristics of a Four-Valve S.I. Engine", SAE P. 930613.

34. Morel, Thomas, and Rifat Keribar. "A Model for Predicting Spatially and Time Resolved Convective Heat Transfer in Bowl-InPiston Combustion Chambers", SAE P. 850204. 


\section{APPENDIX 1}

Table A1 - Parameters of gasoline, E100, M100 and propane fuels.

\begin{tabular}{|c|c|c|c|c|}
\hline & \multirow[t]{2}{*}{ Gasoline } & Ethanol & Methanol & Propane \\
\hline & & E100 & M100 & \\
\hline Chemical formula & $\mathrm{C} 4$ to $\mathrm{C} 12$ & $\mathrm{C}_{2} \mathrm{H}_{5} \mathrm{OH}$ & $\mathrm{CH}_{3} \mathrm{OH}$ & $\mathrm{C} 3 \mathrm{H} 8$ \\
\hline Molecular Weight & $100-105$ & 46.07 & 32.04 & 44.1 \\
\hline \multicolumn{5}{|l|}{ Composition, \% Weight [\%] } \\
\hline$>$ Carbon & $85-88$ & 52.2 & 37.5 & 82 \\
\hline$>$ Hydrogen & $12-15$ & 13.1 & 12.6 & 18 \\
\hline$>$ Oxygen & 0 & 34.7 & 49.9 & 0 \\
\hline Lower Heating Value (LHV) [MJ/Kg] & 43.440 & 26.947 & 20.090 & 46.287 \\
\hline Stoichiometric air/fuel weight & 14.70 & 9.00 & 6.45 & 15.70 \\
\hline Stoichiometric fuel/air weight & 0.068 & 0.111 & 0.155 & 0.064 \\
\hline Energy per kg of stoichiometric mixture $[\mathrm{MJ} / \mathrm{Kg}]$ & 2.767 & 2.695 & 2.697 & 2.772 \\
\hline Research Octane Number (RON) & 95 & 129 & 133 & 112 \\
\hline Latent Heat of vaporization @ $274 \mathrm{~K}[\mathrm{~kJ} / \mathrm{kg}]$ & 348.9 & 921.1 & 1177.0 & 449.2 \\
\hline $\begin{array}{l}\text { Amount of energy available per } \mathrm{kg} \text { of stoichiometric mixture to cool the charge } \\
{[\mathrm{kJ} / \mathrm{kg}]}\end{array}$ & 22.2 & 92.1 & 158.0 & 26.9 \\
\hline Auto ignition temperature $[\mathrm{K}]$ & 516.2 & 681.7 & 722.8 & 708.9 \\
\hline \multicolumn{5}{|l|}{ Flammability limits, volume [\%] } \\
\hline$>$ Lower & 1.4 & 4.3 & 7.3 & 2.2 \\
\hline$>$ Higher & 7.6 & 19.0 & 36.0 & 9.5 \\
\hline Specific heat, $[\mathrm{KJ} / \mathrm{Kg} \mathrm{K}]$ & 2.010 & 2.386 & 2.512 & - \\
\hline Volume \% fuel in vaporized stoichiometric mixture [\%] & 2.00 & 9.00 & 6.45 & - \\
\hline Boiling temperature $[\mathrm{K}]$ & $285.6-483.9$ & 336.7 & 323.9 & 216.7 \\
\hline Flash point, closed cup $[\mathrm{K}]$ & 216.2 & 271.7 & 270.0 & 154.5 \\
\hline Surface tension @293 K [mN/m] & $20.14-21.62$ & 22.39 & 22.50 & - \\
\hline Viscosity@278.9 K [mm²/s] & $0.5-0.6$ & 1.5 & 0.74 & - \\
\hline Specific gravity@274 K & $\begin{array}{l}0.75(0.72- \\
0.78)\end{array}$ & 0.794 & 0.796 & 0.508 \\
\hline Laminar flame speed @ 1 bar and 300K [cm/s] & 33 & 41 & 50 & - \\
\hline
\end{tabular}

